\title{
Rivers we can't bring ourselves to clean - historical insights into the pollution of the Moselle River (France), 1850-2000
}

\author{
R. J. Garcier \\ École normale supérieure, département de géographie, 48 boulevard Jourdan, 75014 Paris, France
}

Received: 10 May 2007 - Published in Hydrol. Earth Syst. Sci. Discuss.: 15 June 2007

Revised: 4 October 2007 - Accepted: 23 October 2007 - Published: 6 November 2007

\begin{abstract}
As products of both natural and social systems, rivers are highly complex historical objects. We show in this paper that historical analysis works on two different levels: one level, which we call "structural", shows the materiality of the riverine environment as the spatial-temporal product of natural factors and human impacts (bed and course alterations, pollution, etc.). On a second level -"semiotic" we show that river systems are also social constructs and the subjects of ancient and diverse management practices. The quality of a river will be a function of the dialectical interaction between both levels. Historical analysis can uncover the inherited constraints that bear upon current management practices. To help substantiate this analytical framework, we analyse the case of the Moselle river in eastern France by using archival sources and statistical data. Severely impaired by industrial discharges from iron, coal and salt industries between the 1875s and the early 1980s, the waters of the Moselle became the subject of a social consensus between stakeholders that prevented the implementation of efficient pollution management policies until the 1990s. The example urges caution on the pervasiveness of participatory approaches to river management: social consensus does not necessarily benefit the environment.
\end{abstract}

\section{Introduction}

The contemporary scientific literature on river systems calls for a better understanding of the relationships between rivers and society (Meybeck, 2002). This testifies to the powerful social dynamics that shape natural objects. At all time and space scales, the impact of human action on natural objects and environments has been getting harder to neglect. The floristic composition of forests, the strength of soil erosion in

Correspondence to: R. J. Garcier

(romain.garcier@normalesup.org) ancient times, the circulation of exogenous species, the presence of lead in Arctic ice all advocate a reassessment of how we theorize, analyze and quantify human interaction with the "natural" world. This is a complicated debate because it develops at the borders of disciplinary fields. It is sometimes difficult to reconcile the concerns and methods of the natural scientists with those of the historians, the philosophers and the sociologists. True interdisciplinarity in the environmental field is needed but hard to achieve.

Rivers are good objects on which to build interdisciplinary research, as the existing literature shows (Petts et al., 1989; Meybeck et al., 1998). History plays a great role in those research initiatives. One reason is that, in the Western world, there is generally a wealth of historical data available on rivers. Very early, the significance of water for human settlements transformed them in legal objects. Roman law developed a large corpus on water rights. Even in those countries where the legal system does not derive from Roman law, the question of water property was never left unspecified. It was of considerable importance to know who was entitled to withdraw water from a watercourse or a water table; who had the right to modify the course of a river to create mills or irrigation works; who was responsible for maintaining the dykes and dams erected to protect the land against floods, etc. As a consequence, public and private archives alike are rich with ancient information about the representations, transformations and management of rivers ${ }^{1}$. Specifics about water abstraction and channel geometry modifications appeared as early as the Middle Ages. Data regarding water quality appeared later, with the development of analytical methods (end of the eigteenth century). In France, the development of spas from the 1830s gave a decisive impetus to the chemical analysis of water and the subsequent development of adduction and sanitation networks made necessary

\footnotetext{
${ }^{1}$ For information about contemporary historical sources for environmental history in France see (Corvol, 1999, 2003).
}

Published by Copernicus Publications on behalf of the European Geosciences Union. 
frequent water quality analyses which have been kept in the archives. The expansion of water quality analyses has been very great since the 1960s, when they were extended to all waters (and not only those used for human consumption). Other sources of data can be mobilized to study the historical evolution of rivers: e.g., field observations, aerial photography, sediment sampling (Meybeck et al., 2007). However, for contemporary river managers and river scientists, the recourse to history may appear like a nice but somewhat superfluous addition to their core business and concerns. In this paper, we would like to argue that a systematic exploration of river history can shed light on many aspects of current river dynamics and politics, especially for those rivers that have been most transformed by human action.

This belief is grounded in a case study that was conducted over five years in Eastern France, on the river Moselle (Garcier, 2005). Over the course of thirty years at the end of the nineteenth century, the Moselle underwent brutal changes. It became the axis of a powerful industrial region, saw its channel considerably remodelled and the quality of its waters progressively degraded. We used archival sources - among others - to reconstruct this transformation and provide some quantitative elements about it. But we also tried to make sense of it: how could a river experience such massive changes without much debate? How come that the local population and administrations quickly saw industrial pollution as normal? What kind of management policies were applied to remedy the problem and with what success? And ultimately, can contemporary river management gain some insight from this retrospective assessment?

We will first provide a theoretical overview on rivers as historical objects and products of socio-natural systems. We will then present the case of the Moselle. We will finally introduce some conclusive comments on the use of historical information to aid contemporary decision-making on river management.

\section{Rivers as socio-natural systems}

In the twentieth century, historiography has undergone important changes that have affected the methods and the objects of historical enquiry. The main reformers of historical practice are the members of the so-called "Annales School", among them Marc Bloch, Lucien Febvre, and later, Fernand Braudel. Their approach promoted the use of adjunct sciences to advance historical research. They were not hostile to scientific inputs from anthropology, sociology and geography and they favoured the use of a variety of information sources. Most importantly, their scientific stance departed from the traditional emphasis on events. As one prominent member of the school puts it, this new approach "relegated the sensational to the sidelines and was reluctant to give a simple accounting of events, but strived on the contrary to pose and solve problems and, neglecting surface distur- bances, to observe the long and medium-term evolution of economy, society and civilisation." (Duby, 1990).

Observing the "long and medium-term evolution" requires studying historical "structures". The notion of structure is widely used in the social sciences and humanities, though its meaning varies. Here, by historical structure, we mean a lasting mode of repartition and organization of social objects and practices. In this historical model, events are a manifestation of structures: no event can happen independently of the structures uncovered by historical scrutiny. As a consequence, no event is "random", completely foreign to the way societies are organized materially but also, culturally. It is another contribution of the Annales school to have specified that structures are not only material but mental as well. Each region and time period has specific ways of thinking that filter experience and steer action or inaction. Accordingly, an idea cannot spontaneously spring in any social structure: it is always dependant on a certain context.

The influence of the Annales school on environmental history has been very great, because environmental change, until recently, has been a "long and medium-term evolution". The new approach opened up the possibility to investigate the historicity (i.e. historical character) of the environment itself by using historical data. Emmanuel Le Roy Ladurie's Histoire du climat depuis l'an mil was the first attempt to use textual data (e.g. the dates of wine harvests in the south of France) to document natural climate variations over historical periods (Le Roy-Ladurie, 1988). The research done by the Lyon's group on river systems shares the same theoretical basis: by using a variety of data sources (geomorphologic field observations, textual and cartographic archives, etc.), it is possible to reconstruct the natural evolution of a watercourse over many centuries if not millenia (Roux, 1982; Bravard, 1989; Girel, 1996; Bravard and Magny, 2002). Environmental change modifies the whole fluvial system. Rivers respond by reshaping their beds. Depending on water conditions and the availability of sediments, a river will cut its bed or expand it by aggradation.

Other research stances take up a slightly different approach; they insist on the impact of social structures and economic development on the environment - see for example Cronon (1992) and Williams (1992). The river "biographies " that have been published in the last fifteen years share the same line of thought. In those works, the river system and basin are not considered as the setting of historical events nor are they considered as purely "natural" entities. Indeed, the main driving force of change is human action, and especially, industrialization and urbanization (Barca, 2007). Steinberg has shown how the pristine waters of New England were "incorporated" into the cotton mills built by Bostonian capitalists in the early 1830s (Steinberg, 2001). Cioc studied the case of the Rhine and the continuous stream of alterations and modifications applied to the river channel and flow by human action (Cioc, 2002). In an equally severe case but different context, Gumprecht has analysed how the city of 
Los Angeles has slowly preyed upon the Los Angeles River, diverting its waters and finally casting it into a casement of concrete to prevent flood damage (Gumprecht, 2001). In all cases, historians have shown that some rivers in the Western world have been severely impacted by human action. Their evolution is driven by socio-economic factors as much as by natural ones.

This has been theorized by the sociologist Ulrich Beck in his famous book Risk Society (Beck, 1992). Written in the wake of the Chernobyl accident, Beck's book was mainly concerned with nuclear risk. However, Beck has shown more generally that industrialization has brought, or "integrated", natural objects into the social world. Natural objects have become technical elements within the industrial system: they are one of the industrial production factors. This seminal idea works extremely well when applied to rivers. With industrialization, the technical means to harness nature, the variety of water uses, the quantity of water, the corrections applied to channel geometry and of course water pollution have reached levels never seen before. As a consequence, it has been increasingly difficult to separate rivers from the social and geographical context in which they are enshrined because many aspects of contemporary rivers, even some of their "natural" dynamics, are driven by social demands and uses. This is especially true on those rivers most transformed by human action.

For such objects, it is irrelevant to speak of "natural" objects impacted by society. There is a complete interpenetration of the fluvial system and socio-economic system that gives birth to another object that is neither natural nor social. On a more general stance, to account for environmental impacts in rivers, it is rational to discard the Nature/society dialectics that has been under heavy criticism for conceptual reasons ${ }^{2}$ and move forward towards a more integrative framework. This framework would first of all concern itself

\footnotetext{
${ }^{2}$ Sociologist Bruno Latour has shown that even in the western world, this divide was never as perfect and definitive as we like to think it was (Latour, 1993, 2004). He argues that there have been permanent and often unsuccessful efforts to insulate natural objects and scientific facts and practices from the "contamination" of social values. In his view, scientific practices that have reinforced the Cartesian distinction between Nature and society from the sixteenth century onwards have never been free from social interference. Accordingly, we cannot claim to have an absolute knowledge of Nature, simply because Nature is socially constructed through scientific practices that categorize arbitrarily objects and situations as "natural" or "social". In another strand of criticism, anthropologist Philippe Descola has shown that the relationship between people and natural objects (e.g. wild animals) is negotiated in different ways in different societies (Descola, 2001, 2005). Some societies do not draw a sharp distinction between what belongs to the human and social world and what belongs to the natural world. Even non-animated objects (river, trees) can have the same social standing as individuals. In other words, the distinction between Nature and society is not anthropologically invariant across cultures but is historically and socially constructed.
}

with all the material aspects of rivers. If archival data is rich enough, historical analysis can provide many insights on the material and spatial configuration of such socio-natural river systems and on the flows of water and matter that transit through them. This is where the concept of "anthroposystem" is useful. An anthroposystem, according to M.A. Santos, "is an orderly combination or arrangement of physical and biological environments for the purpose of maintaining human civilization." (Santos and Filho, 2005, p. 80). The concept of anthroposystem describes the metabolism of the river in a way that makes sense to the hydrologist, the geochemist, the historian and the geographer. The concepts of "anthroposystem" and "historical structures" have a strong affinity because reasoning historically in terms of "structures" opens up the possibility of modelling and quantification since a material structure can be rendered by a system ${ }^{3}$. This affinity is obvious in the studies that analyse the past metabolism of cities (Barles, 2002, 2007; Laakkonen and Lehtonen, 1999).

However, beyond this "material" level of historical analysis, another level has to be taken into consideration. Some younger members of the Annales School have argued that historical structures do not only reside in material elements. Some cultural elements are shared among people and constitute mental structures - sets of values, of automatic thought reflexes, of legitimate practices. In short, mental structures, or "mentalités", control what people collectively think and collectively accept. A person is not always conscious of the mental structures that categorize his or her thoughts. On a personal level, however, a person can rebel against them. On a more general scale, it is not the case and the ways of thinking that are recurrent and dominant can be outlined by historical analysis. Sharing some mental structures does not mean that all social actors agree nor have the same interests but they have an identical way of analysing a situation or responding to a problem. Mental structures encompass struggle between interest groups: they provide a background and the lines along which issues are debated. In other words, mental structures frame social debate about issues, policies or objects. They will endow some objects with certain sets of values and rivers are no exception to the rule.

This is why the anthroposystem concept does not capture all the complexity of the social representations of rivers. Rivers are not only material objects; they are also cultural entities which interact with the social system. This is how Richard White interprets the remaking of the Columbia River as an "organic machine". He explains that when Americans were acting on the river, they were indeed "Emersonians": Ralph Waldo Emerson's books provided the cultural background against which Americans could make sense of the rivers that they were modifying to suit their needs. Harnessing the river's power and organic cycles (most notably that of

\footnotetext{
${ }^{3}$ This idea was put forward by Raymond Boudon as early as 1968 (Boudon, 1968).
} 

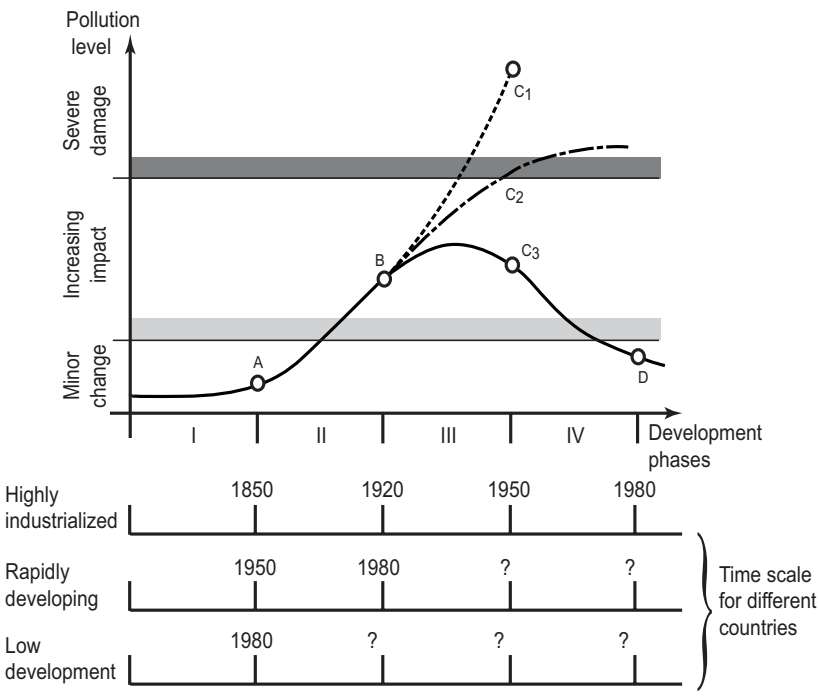

A pollution increase linear with population increase (rural society) A-B exponential increase of pollution with industrialization

B--C1 no pollution control enacted

B--C2 some controls installed (e.g., mechanical sewage treatment)

B--C3 effective controls consistently employed (e.g., mechanical-biological wastewater treatment)

C3--D recovery of pollution situation to a tolerable environmental status due to effective source control and/ortertiary treatment of effluents

Fig. 1. Conceptual model of pollution occurrence and control taking organic pollution in Europe as an example. Source: after Meybeck et al. (1989).

salmon) was a way to connect to the larger cycles of life and nature (White, 1995). In another geographical setting, Philip Scarpino states that link clearly:

"The transformation of the Upper Mississippi and the Missouri Rivers that took place between the mid-nineteenth and the mid-twentieth centuries was solidly rooted in attitudes - in the way that many Americans defined nature and the appropriate relation between humans and nature. In this way, rivers served as a metaphor for the larger American environmental experience." (Scarpino, 1997, p.2).

The same can be told of other rivers, which do not only convey water but values also. The Rhine, for example, has always been a strong symbol of German unity - and the German Moselle itself benefited from the Third Reich Law protecting landscapes meaningful for national identity, the Landschaftsschutzgesetz of 1935 (Chaney, 1996). The rivers in the most industrial parts of the French Moselle basin were also endowed with sets of values. We possess archival evidence of the specific status granted to these rivers and river sections by industrialists and managers (see below). We do not base our argument simply on wide historical inferences but on actual textual evidence. Analyzing the representations of rivers - the "images" people have of them - is useful be- cause they have an impact on river use and management. The image of a river can be invoked to dispel any change or use deemed illegitimate and incompatible with it. In the 1990s, all plans to further dam the Loire river in France were dropped in front of the fierce opposition from local populations and environmental activists putting forward the need to protect the unique character of "the last wild river in Europe".

We would call this level of historical analysis "semiotic" because rivers are treated as signs conveying meanings or values. The meaning presently controls what can be done on or with the watercourse. Accordingly, river management is not only a matter of conscious decisions and objective rationality: it also depends on the mental structures and the image of the river stakeholders have. When we judge that a river has been badly managed, the explanation is not necessarily scientific ignorance or the incompetence of river managers. It may be that the conditions of possibility of a good management could not be met because of an inadequate legal framework, of specific power relations inside the river basin or because of incompatible mental structures. Political decision-making is not a simple, linear process and in the long run river management is the dialectical product of a combination of material processes, socio-economic factors and mental structures.

\section{Applying the conceptual model: the example of water quality of the Moselle}

These general considerations can be readily translated into concrete research practices. The case of the pollution of the Moselle is an interesting real-life example because it was the outcome of an interplay between radical structural changes brought by industrialization and the development of new attitudes towards the river itself. In the second part of the nineteenth century, the socio-economic specialization in the drainage basin changed dramatically from agricultural activities to heavy industry. The Moselle and many smaller rivers in its drainage basin were modified to suit industrial needs. The quality of surface waters in the basin was of course adversely impacted by these developments. We tried to quantify this negative impact and identify the material and mental structures that made it possible or gave birth to it. Finally, we tried to link the material data ("how much pollution?") with the political reaction and management initiatives that were taken at the time.

\subsection{A conceptual model of pollution level}

To this purpose, we used a model proposed by Michel Meybeck and al. that links pollution discharge, economic development and political reaction (Fig. 1). Two categories of variables influence pollution level. On the one side, aggravating factors such as population and economic growth (and especially, industrial growth); on the other, limiting factors such as the presence of sewage plants or the implementation 
of efficient control strategies (pollution taxation, for example). This conceptual model assumes some kind of link between the pollution level and the political reaction since inflexion points appear at certain moments in time and give birth to various scenarios. However, it does not specify the nature of this link: how does the pollution level influence the decision process that leads to management initiatives? In turn, what is the impact of management strategies on pollution levels? And more generally, would historical hindsight back up the model assumptions? My point here is that on the Moselle, there is no direct connection between the objective level of pollution and the social and administrative response to it, because it is not because people "become aware" of a problem that it will be solved - precisely because of the inertia of historical structures, whether material or mental. Polluting a river is socially acceptable if its only value is to serve as an industrial tool.

The data sources used to specify the model are diverse. France has a tradition of public administration of natural objects. This derives from Gallic legal idiosyncrasies, most notably the eminent role of the centralised State as a landowner. Moreover, through law, the State - and not the judge - is the primary socio-spatial regulator. The State is the rightful owner of all rivers deemed "floatable and navigable" (for an overview of history of the French water law, see (Gazzaniga et al., 1998)). It does not own the water, which in French law has always been "res communis" - the property of all - but it owns the banks and the bed. For smaller rivers that can be privately appropriated, the State still has a right to validate the use owners make of water because he should guarantee the mutual compatibility between all the water uses of a river. Accordingly, vast amounts of technical and management data on rivers can be found in the public archives kept in every "département". The continuity of the State from the early monarchies to contemporary day through the Revolutionary period enables one to have spectacular historical depth. To reconstruct the modifications applied to river beds in the Moselle basin, we primarily used reports from the civil engineers' bodies in charge of the management of rivers. These reports sometimes provide more general overviews on water uses in a "département" or on a river and sometimes include statistical data. Two main bodies have been in charge of river management. For the smaller watercourses ("non-navigable and non-floatable"), it has been the corps of the Génie rural et des Eaux et Forêts. For the larger watercourses (i.e. "floatable and navigable"), the corps of the Ponts et Chaussées and more specifically, the Service de la navigation have taken responsibility. In the Moselle basin, however, there have never been such influential engineers as Tulla on the Rhine (whose action is thoroughly analysed by Blackbourn (2006, pp. 76119)). Two reasons explain this. First, the chief engineers have to move periodically to other parts of the country to prevent their being involved in local politics and compromises. Second, there has never been on the Moselle such a service as the Service spécial du Rhône which guarantees a long lasting river management philosophy, beyond individual people.

Other public technical bodies (first, the Inspection du Travail then the Corps des Mines) have been in charge of the overview of industrial activities. Since 1810, France has had a legal framework that categorizes industrial activities according to their level of nuisance. Three categories have been created and for the first two, public authorization is necessary to create a plant. An order of the prefect (the representative of the State in every "département") allows an industrialist to proceed with the construction of the plant but specifies by what norms the plant operation should abide. The demands of the industrialists, the technical documentation they provided, the answers of the technical bodies and the prefect can all be found in the public archives, where they are classified on a communal basis. They provide a very interesting source of information on industrial discharges. Moreover, the technical bodies in charge of the industrial sector were responsible for the compilation of production statistics. Production statistics are also available for publicly owned companies most notably Charbonnages de France, the coal production monopoly created by the nationalisation and merger of independent mining companies after World War II (HBL, 1993; Haby, 1965).

For private companies, the situation is more complicated, because even if they still exist, they seldom have archives available for historical research. One exception is the steel company Arcelor, which set up a specific archival service, gathering all the archives from the various steel companies that merged over the years (referred to in this paper as "Espace Archives Arcelor").

Finally, since World War II, France has devised numerous national and regional development strategies to compensate for territorial inequality and especially for the weight of the region of Paris. These strategies were translated into policies at the regional level. In face of vigorous industrial and urban growth, water was becoming a limiting factor of regional development in the 1950s. To forestall that ominous prospect, public authorities devised the 1964 Water Law that created basin agencies and water taxes based on polluter-pay principles. The Rhin-Meuse basin agency has been, since its debuts, a huge provider of data on water and watercourses. They have been in charge of the equipment of the basin with sewage treatment plants and large amounts of documentation are available in their archives.

\subsection{Industrialization, evolution of historical structures and} water pollution issues in the Moselle basin

The Moselle is the main tributary to the Rhine. Its river basin has a surface of $28280 \mathrm{sq} \mathrm{km}$ and is shared between three countries. France has slightly more than $50 \%$ of the basin, and most of the headwaters. Luxembourg has $15 \%$ of the basin, through sovereignty over most of the river Sûre 


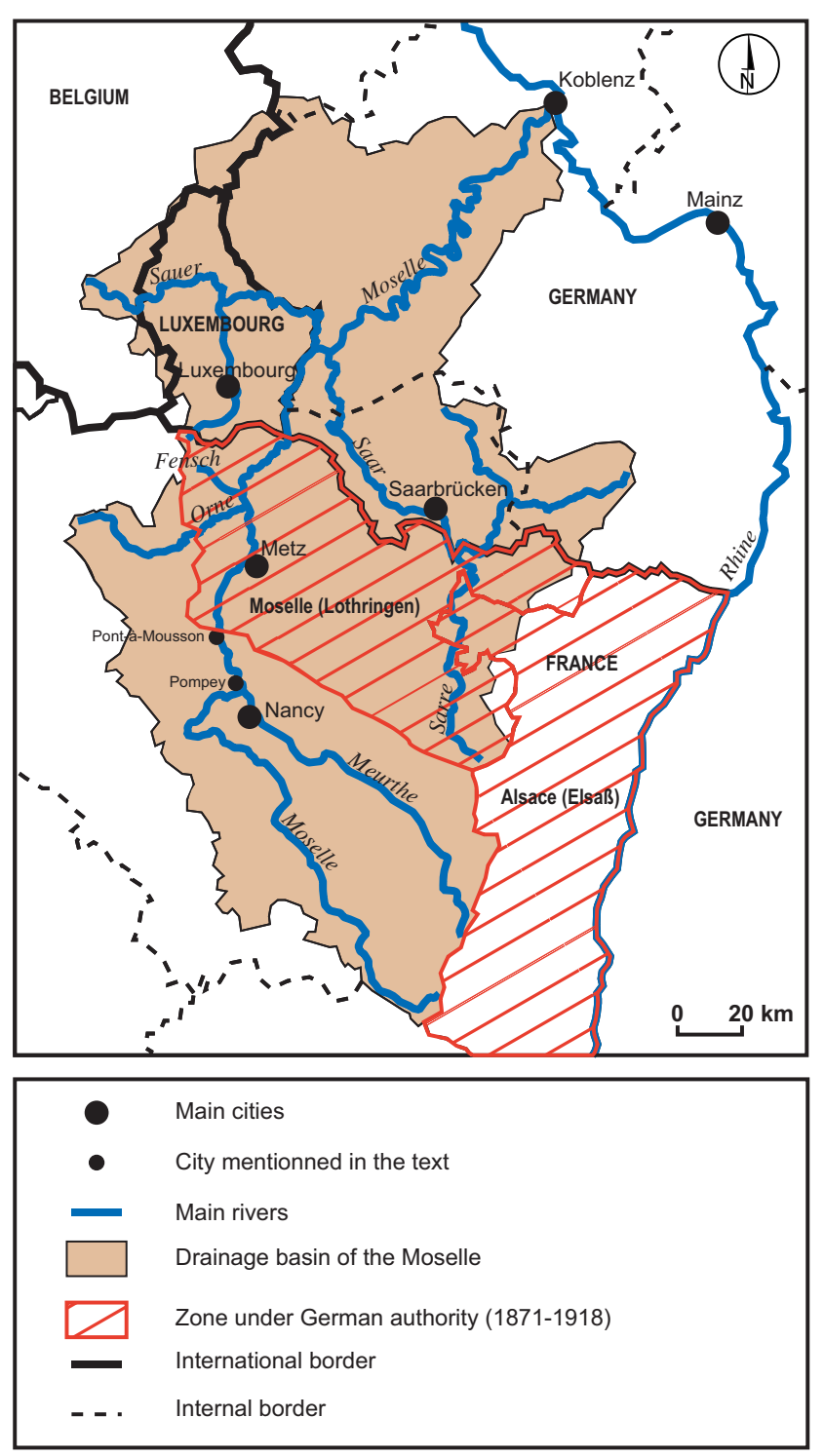

Fig. 2. The drainage basin of the Moselle.

(Sauer) ${ }^{4}$. Germany has the lower course of the river, down to the confluence with the Rhine, at the Deutsches Eck ("German Corner") in the city of Koblenz (Fig. 2).

\subsubsection{From the agrarian to the industrial river}

Historically speaking, the Moselle has been documented by text archives since Roman times. It was then an important axis of circulation between the North and the South of Europe and the city of Trier, in contemporary Germany, was the capital of the province of Belgium. A long poem by Auso-

\footnotetext{
${ }^{4}$ In this paper, we generally use the French names of the rivers. However, we will also provide the German names when appropriate.
}

nius (fourth century) dedicated to the river provides the first known mention of water mills in Europe, an indication of the ancientness of human action on the river itself (Bloch, 1935). The Moselle, however, was never modified significantly before industrial times, because of hydro-geomorphological constraints and historical circumstances. The river carried a large amount of bed-load that proved to be a severe obstacle to fluvial navigation and human settlement. The river was constantly changing its course on its flood plain, acquiring a reputation of "treachery" and making itself extremely difficult to control (Le Masson and Le Joindre, 1835). Navigation was further impeded by the political segmentation of the river after the demise of the Carolingian Empire (ninth century). All local authorities levied large tolls on navigation, providing a strong disincentive to the development of commercial flows and making any project of course rectification irrelevant. Quite paradoxically, the Lorraine region was not organized around its main river. Local uses were dominant: the river served as a source of fish and its floodplain was used to raise cattle. As a consequence, before the 1850s, most rivers in the Moselle basin, including the Moselle itself, were in a subpristine state ${ }^{5}$. Fish was plentiful and renowned and the riparian landscapes were celebrated - specifically in the German part of the basin, where the Moselle meanders in vine-covered gorges. The only exception in the basin was the Saar river in Germany. In the Saar region, coal mining was an ancient activity that received a new impetus under the leadership of the Counts of Nassau-Saarbrücken (mid-eighteenth century). In the 1820 s, after the merger of all mines into a single organisation overseen by the Prussian state, production reached an industrial scale. The introduction of steam engines in mines allowed for the creation of new mine pits and the expansion of existing ones through the pumping out of underground waters. The spatial and quantitative expansion of mining activities had a strong impact on the regional environment. The first reported consequences were soil subsidence and the disappearance of springs, which forced the local authorities to encourage a centralised water distribution system (Kraemer, 1999). Later, in the 1850s, induced activities such as iron production began to impact adversely the quality of the Saar in Germany (Dülmen and Labouvie, 1992).

In the French part of the basin, industrial development happened later than in Saarland but with spectacular strength and rapidity (Bour, 1995), bringing unforeseen structural changes to the region and the river. Industrial growth was based on the three valuable ores that can be found in Lorraine (see Fig. 3): coal, iron and salt. The coal seam in France is in the continuity of that of the Saar and was mined industrially

\footnotetext{
${ }^{5}$ Some exceptions are documented in the grievances books requested by the Revolutionary power in 1789 . For examples, some stakeholders of the Fensch river complained about the impact of mining and proto-industrial activities of the Wendel ironworks, but these complaints remained extremely local.
} 
from the 1840s. In the east of the region can be found massive amounts of low-content iron deposits. The local pig-iron industry, located in the mining areas, transformed itself into a very powerful steel industry after the technical process to eliminate the phosphorus contained in the local ore fell into the public domain in 1893. Finally, the geological salt deposits found in the region served as raw material for various chemical industries, the most notable being the soda plants using the Solvay process (founded between 1871 and 1910). Other industries had developed earlier, and locally, their impacts were significant. At the head of the basin, the Vosges mountains provided good conditions for the textile industry. After the annexation of Alsace and the northern part of Lorraine by Germany in 1871, this industry received technical, human and financial support from the Alsatian industrialists who had decided to leave Alsace to remain in France.

The industrialization process triggered three main lines of structural changes for the rivers in the basin. First of all, a large majority of the new plants favoured locations close to the watercourses because they needed the proximity of water. Water served as an input in some industrial processes (steam production for example), as a cooling fluid and also, as the receptacle of industrial effluents. From the 1850s, all newly created plants in the Moselle basin were located in close proximity to the watercourses. This profoundly modified the riparian landscapes, specifically in those areas where industrial clusters developed around specific industries (steel, soda, etc.). Moreover, it increased competition for water between existing users and the new large industrial plants. When arbitration was needed, the advantage was often given to the most capital-intensive users. This process can be seen as early as the 1860s in Saarland: at this date, a paper mill in Dillingen filed a lawsuit against the steel factory of the same city, which was consuming most of water of the Prims and polluted the rest in such a fashion as to make the production of paper impossible. The paper mill lost its lawsuit, which brings Richard Van Dülmen and Eva Labouvie to say:

"From that period, the water needs of a paper mill had to yield in front of those of a heavy industrial plant." (Dülmen and Labouvie, 1992, p. 67)

Second, the industry needed enhanced transportation, because it imported some raw products and exported much of its production to other parts of the country or abroad. Railway played a role but other cheaper alternatives were also considered and especially the building of canals. From the 1870 s, there was a constant drive to upgrade the canal system in the region. The notorious "Freycinet plan" of 1879 planned to build $1400 \mathrm{~km}$ of canals in France, a large part of them in industrial areas. From then on, the Moselle itself underwent constant rectification works to suit the needs of the industry (Cermakian, 1975). The most telling example is the Canal des Mines de Fer de la Moselle that was opened in 1932. The canal was built by private interests to bring in coke imported from the Ruhr and export iron products to the Bel-

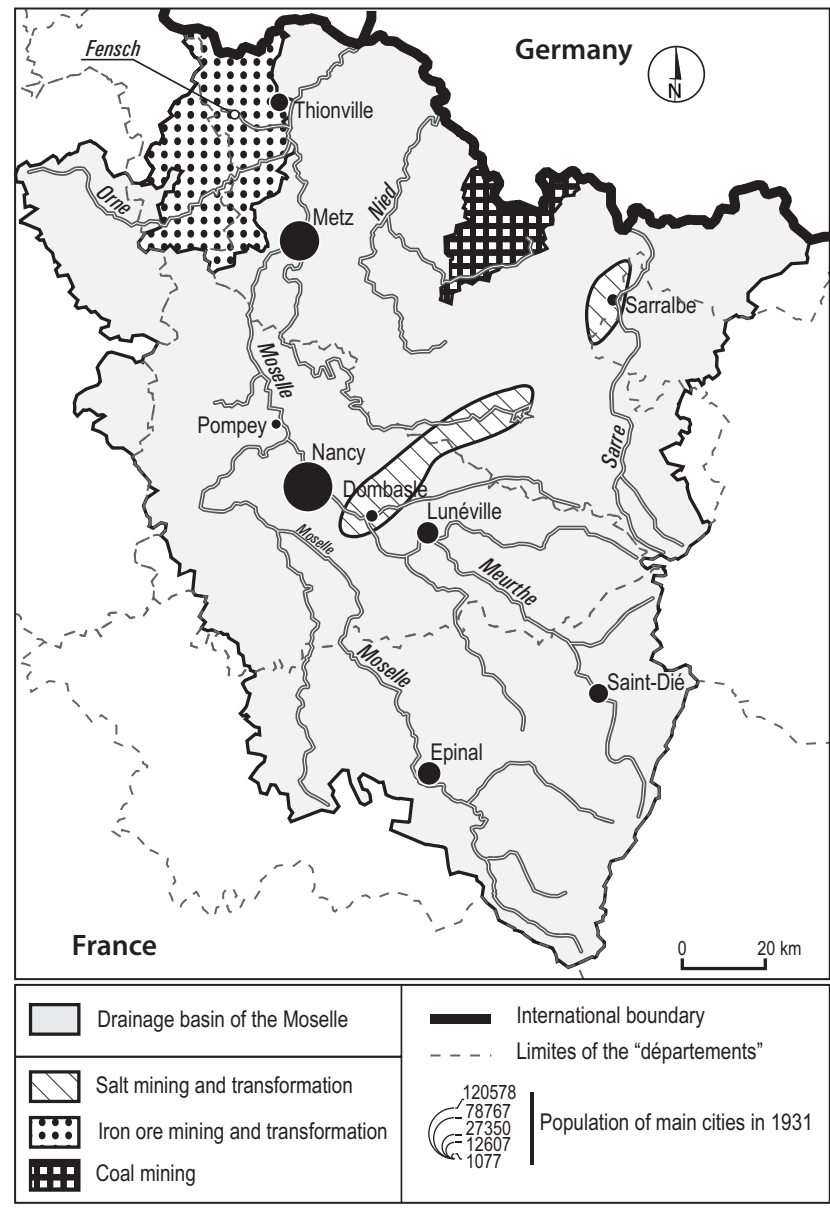

Fig. 3. Spatial specialization of industrial development in the basin of the Moselle.

gian and Dutch ports through the Rhine system. It consisted of two sections: one was built in the Moselle floodplain, parallel to rhe river; the other used the river channel itself that was thoroughly dredged. The drive for canalization went further and in 1964, Rhine-type barges could navigate upstream up to Nancy ${ }^{6}$. The rectification process proved detrimental to water quality, because it disrupted the dynamics of natural self-purification by removing riparian forests and wetlands.

The third structural change that affected the region and the river was the growth and spatial reallocation of population. The region lacked unskilled workers and the industrialists and mines had to organize immigration networks to bring workers from Poland, Belgium and Italy first and from Northern Africa after World War II. Some cities in the most industrial parts of the basin experienced spectacular growth. This called for a complete upheaval of urban water provision, since the traditional modes of water provision and evacuation

\footnotetext{
${ }^{6}$ Before that, only 350 tonnes barges could navigate on all of the canal system. From 1964, the waterway was open to 1200 tonnes barges.
} 


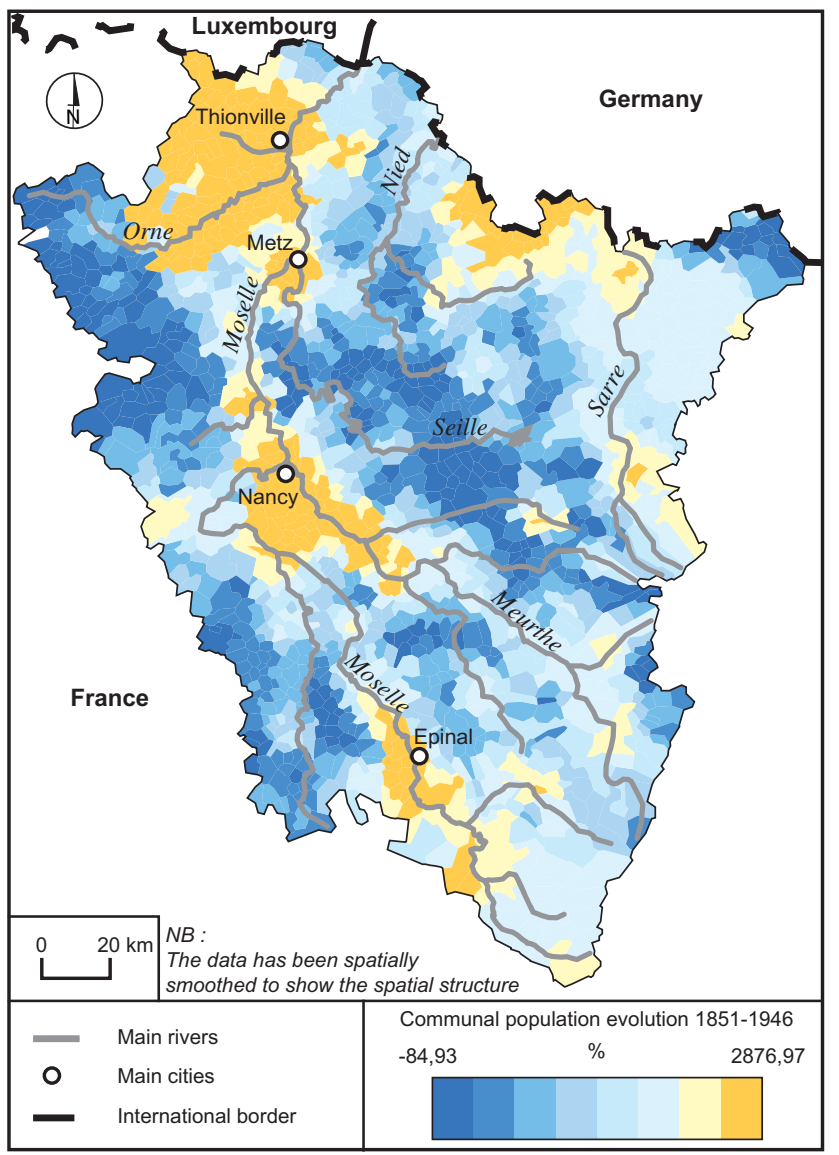

Fig. 4. Evolution of the communal population in the Moselle basin in France between 1851 and 1946.

were quickly outpaced by the rhythm of urban expansion. Water was essential for urban growth. In the mushroom cities created by industrial activities, it became standard to have access to large amounts of flowing water for domestic and urban uses. Waste waters were then rejected without treatment into the natural environment through the sewer systems that were extensively built in the region between 1870 and 1950 . In 1946, a study counted only three existing urban waste water treatment plants in the whole Moselle basin, two of which had been out of order for at least six years. Quite predictably given the experience of other cities in France, England or Germany, the development of urban hygiene in the cities of the Moselle basin resulted in severe degradation of the watercourses by organic pollution of domestic origin. Figure 4 illustrates the changes brought about to the existing spatial structure of population in the basin between the 1851 and the 1946 census. The main axis of the river system, the large cities and the industrial basins concentrated most of the population growth. The more rural areas in the centre and in the west of the basin experienced depopulation. The net result was a changing geography of pollution, with increased ur- ban pressure on watercourses in those areas where industrial pressures were already very high.

However, there was another type of change induced by industrialization. The coming of age of a powerful industry progressively modified the "semiotic" status of rivers for local societies. The transformation of rivers from natural objects into industrial tools was gradually vindicated in the region. Around the 1870s, there still were strong debates about the legitimacy of industrial impacts. An ingénieur de la navigation gave this warning about the proposed creation of chemical plants on the river Meurthe:
"Should the Meurthe receive without restriction the waste waters of all these plants (how harmless should any individual discharge be), this pure and limpid river would very soon be profoundly altered [in French: dénaturée] and could not provide any- more the riverside residents with the services from which they benefit today and are entitled to." 7

The city of Nancy, located downstream of a proposed plant, notified its disagreement too:

"The municipal administration is convinced that this project would have the direst consequences for our city. Under a first layer of vegetal earth, the Meurthe valley is filled, on all of its length, by a layer of granitic sand and gravel which thickness varies between 3 and $10 \mathrm{~m}$. This layer of rather pure alluvium contains the underground water table which supplies water to the population of the valley and especially to a large part of the population of Nancy." 8

However, these projects were allowed to proceed, for two main raisons. The first one is that some stakeholders found technical solutions to accomodate the new factories. For example, the city of Nancy turned to other sources of drinkable water and started to discharge in the Meurthe the untreated waste waters collected by the sewer system it built in the 1880s. The second reason is that industrial development was seen as more important than the preservation of streams themselves. Instrumental rationality justified the artificialization of the river system. By 1910s, barely a voice contested the legitimacy of the industrial "take-over" of the rivers, because of the economic importance of the industry itself, but also because preserving the streams was not an overwhelming concern. The stream had no value in itself. This was theorized by German scientists working in the Rhine basin. The

\footnotetext{
${ }^{7}$ Archives départementales de Meurthe-et-Moselle, file 5 M 167. Chief Engineer's opinion, in: Report of the Ingénieur ordinaire de la navigation on the creation of a potassium cyanide plant in Laneuveville-devant-Nancy, 16 December 1871.

${ }^{8}$ Archives départementales de Meurthe-et-Moselle, file 5 M 167. Observations adressées à M. le Préfet de Meurthe-et-Moselle [...] relatives au projet de la fondation d'une usine de produits chimiques à la Neuveville, Paris, Seringe Frères, 1872, p. 5.
} 
best known of them, Curt Weigelt, was originally working as a fish expert in Alsace. He was the first to study methodically the impact of industrial effluents on fish life (Weigelt, 1885). However, by 1900, he was hired away by the German Chemical Industry Syndicate (Buschenfeld, 1997, p. 71) and started to write scientific pieces favourable to industrial discharges. He introduced the concept of Opferstrecke ("sacrificed section"). His work was translated into French and was known by river managers in Lorraine, on both sides of the border. Here is what Weigelt meant by "sacrificed section":

"Every time that a process capable of purifying the wastewaters cannot be implemented because of its excessive cost, it should be allowed to sacrifice a section of the stream to the partially treated wastewaters, in order to make use of self-purification. However, this sacrifice cannot be made in favour of raw, untreated waste. In general, the maximal length of such a sacrificed section should not exceed three kilometres." (Weigelt, 1903, p. 556)

This concept was put to use in the Ruhr region as early as 1904 and very soon, its scope expanded beyond its initial, fairly prudent, formulation. The river Emscher was modified to become a major industrial wastewater collector (Held, 2002). This functional view of rivers was also present in the Moselle basin (most notably on the Fensch and the Orne) and the "sacrificed section" model endorsed by the Administration. In 1910, for example, here is how an industrialist describes the visit made by a German expert on the Fensch to assess the seriousness of water pollution:

"The baron of Richthofen [the expert] has been very amiable with us. He repeated again and again that he knew exactly and had known for a long time the situation on the Fensch. Industry, he said, certainly contributes a large part to the impurities discharged in the Fensch but from another standpoint, without the industry, what would have become of the entire region?"9

The concept legitimated the devolution of river portions to industrial pollution when no other economically sensible solution was available to preserve industrial prosperity ${ }^{10}$. Later

\footnotetext{
${ }^{9}$ Espace Archives Arcelor, file V10/150. Account of the field visit of 20 April 1910, 18 May 1910, p. 9.

${ }^{10} \mathrm{We}$ cannot provide here a detailed comparison of the French and German pollution management models. They were not very different because they shared the same legal basis. When Germany annexed a significant portion of Lorraine and the totality of Alsace in 1871, French law was granted the status of local law. The French laws prohibiting pollution or enacting administrative oversight of industrial operations were still valid. It was only progressively and not even fully that French law was replaced by local laws devised by the local parliament of the Reichsländer of Lothringen and Elsaß.
}

on, the functionalization of rivers was theorized even further and granted a moral and aesthetic status. In the conclusion of a book commissioned in 1932 by the Commerce and Industry Chamber of the city of Metz to celebrate the completion of the Canal des Mines de Fer de la Moselle, the author writes:

"And now, we will go see the finished works. Some will regret the modification of a familiar landscape. [...] But the consideration of the wealth, the jobs, the affluence brought to our region by the completed works will console the poet, the fisherman and the stroller alike. And then, will the landscape be less beautiful? [...] Some landscapes are divine, some are artistic but some others are simply human. They bring about, more than others, work and travel; they induce, as much as others, meditation. Some have said, maybe with a little pomposity, that factories were cathedrals of labour and they have been celebrated by a poet, the poet of sprawling cities, of the great Flemish towns [Emile Verhaeren]. Likewise, canals are rivers of labour; and these rivers are beautiful." (Houpert, 1932, p. 172)

It could be argued that these examples are partisan expressions of economic interest and ways of advocating changes that were only profitable for a wealthy minority. However, these attitudes towards the rivers were widely shared and proved historically long-lasting. The radical transformations brought to socio-spatial structures and river functions meant that those stakeholders (peasants, fishermen, etc.) who had an interest in preserving the agrarian Moselle were progressively replaced and outnumbered by those (the majority of population) who benefited from industrial prosperity. For the latter, the river was an essential part of a larger scheme, of the great industrial narrative of Lorraine which had been celebrated at the beginning of the twentieth century by the likes of Laffitte (1912) and de Launay (1912). It became very difficult to criticize an industry that had brought prosperity to a poor region and that was a cornerstone of French military security, scientific progress and national pride. For example, the iron used to build the Eiffel Tower in 1889 came from the Pompey plant, right by the Moselle. Lorraine, more generally, served as a display of all the attributes of French modernity in front of the perceived menace of Germany. In this context, the standing of the Moselle and its tributaries as objects of discourse changed alongside their structural characteristics. Once firmly in place, the functional vision of the Moselle as a backbone of industrial development was very difficult to reverse and it had a strong impact on pollution management.

\subsubsection{How much pollution was there?}

These historical developments explain, to a large part, the increase in water pollution since the 1850s: the objective 


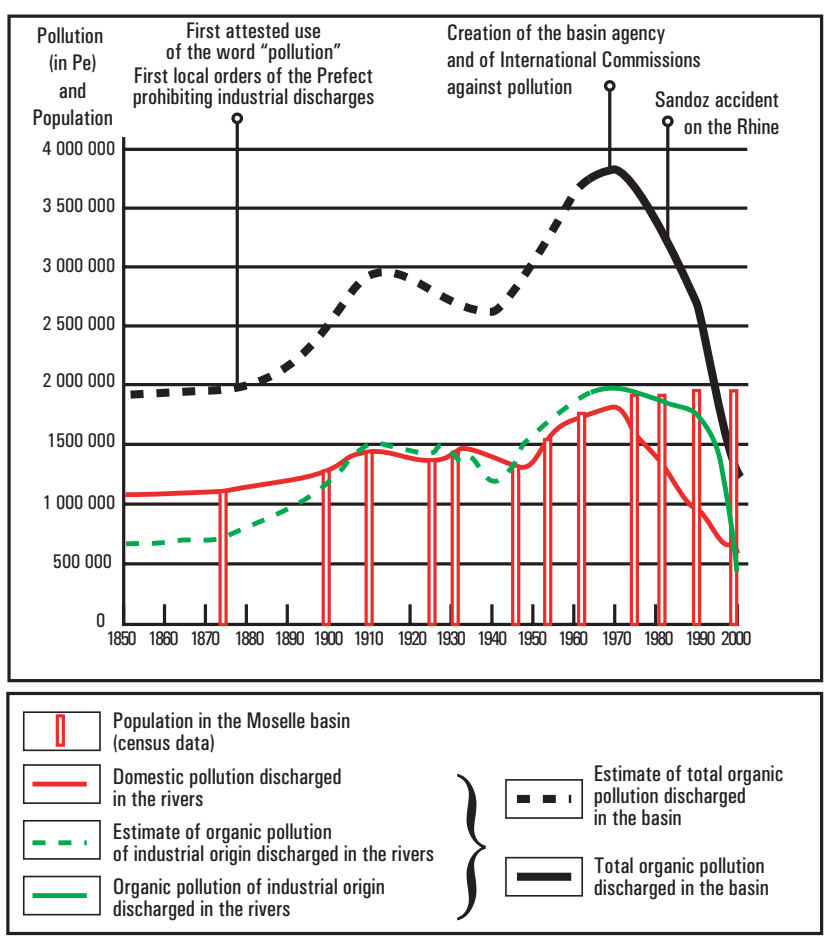

Fig. 5. Estimation of organic pollution discharge from domestic and industrial sources in the basin, 1850-2000.

pollution discharged into the streams from industrial and domestic sources was vindicated by the strong economic and symbolic status acquired by heavy industry and by evolving social values invested in rivers themselves. On these grounds, all pollution management strategies stumbled on the objective and semiotic factors linking industry and rivers.

Figure 5 provides a summary of organic pollution discharges in the French Moselle basin (including the French portion of the Sarre basin) since 1850. It is a rendition of Meybeck's curve applied to historical organic pollution. A few provisos have to be made. The unit of measure is the Population-equivalent $(\mathrm{Pe})$, which is an aggregated index widely used in sanitation projects ${ }^{11}$. The great advantage of using this index is that it enables one to compare domestic and industrial pollution. Domestic pollution was obtained by collecting census data. We considered that before 1965 all waste waters were rejected in the environment without

\footnotetext{
${ }^{11}$ The definition of the Population-equivalent is variable across countries and time periods. Here we follow the French practice of the 1980s and consider that one Population-equivalent is the equivalent of a daily discharge of 180 litres of wastewater containing: 57 grammes of $\mathrm{BOD}_{5}, 135 \mathrm{~g}$ of COD, $9.9 \mathrm{~g}$ of nitrogen and $3.5 \mathrm{~g}$ of phosphorus. Article 2 of the European Council Directive 91/271/EEC of 21 May 1991 "concerning urban waste-water treatment" simplifies the definition by considering that one Populationequivalent is worth a daily discharge of $60 \mathrm{~g}$ of $\mathrm{BOD}_{5}$.
}

treatment. This provides a high estimate for the years before 1870 , because we consider that domestic waste waters were rejected directly into the streams by the sewer system, whereas in fact, sanitation networks were less common than cesspools at the time. After 1965, the construction of some large treatment plants began, removing an increasing proportion of pollution by direct discharge. To evaluate organic pollution of industrial origin, we used production statistics found in the archives for the most polluting industrial sectors: iron industry and coal mining. The equivalency ratios between actual industrial pollution and its measurement in Population-equivalent were drawn from a document published by the basin agency in $1965^{12}$. The dotted lines indicate a tendency when the data is too sparse to provide robust values. The plain line indicates values given by the basin agency itself in published documentation.

Mineral and toxic pollution are not included in the chart. Mineral pollution in the basin originates in the calcium chloride discharges in the Meurthe by the small numbers of soda making plants located south of Nancy in Dombasle. The pollution curve for these plants would be somewhat different, showing a succession of plateaux, because the amount of soda the plants have been allowed to produce and the amount of salty compounds they have been allowed to discharge have always been precisely defined by administrative procedures. In 1873, the Solvay soda plant made a total of 3300 tons of soda. By 1904, the combined production of all the soda plants reached 206000 tons $^{13}$. Toxic pollution is impossible to chart, because no consistent data has been collected before the mid-1980s. This absence is surprising. The production of toxical compounds (phenols, cyanides) by the iron and coke industries has been documented since the end of nineteenth century. However, using proxy techniques to document the evolution of toxic and heavy metal pollution (as do Meybeck et al., 2007) would probably be difficult, because most industrial rivers in the basin have been dredged and recalibrated a number of times. We lack the undisturbed settling ponds needed to measure heavy metals loads in sediments. Further studies would be needed to build the toxic pollution curve.

The organic pollution curve has two modes. A high point was reached just before World War I, when industrial development in the basin was buoyant. World War I brought things to a halt since the northern part of the basin was very close to the combat zones and industrial infrastructures were destroyed during the conflict. Recovery was impeded by the economic crises of the 1920s and 1930s then by World War II. Between 1919 and 1945, the economy did not substantially grow and the pollution level was accordingly fairly stable. It did not reach its 1913 mark before the beginning of

\footnotetext{
${ }^{12}$ This document is kept at the Archives départementales de Meurthe-et-Moselle, file W 124599.

${ }^{13}$ Statistics kept at the Archives départementales de Meurthe-etMoselle, file 1485 W 29. For other soda files, see 5 M 152, VC 4456, W 1245115.
} 
the 1950s. After that date, strong economic and industrial growth induced a sharp increase of pollution.

The highest level of organic pollution in the basin was reached at the beginning of the 1960s. After that date, the decline of pollution owes to the reduction of domestic effluent (all the more remarkable because population numbers were still going up at the time). Organic pollution of industrial origin was abated more slowly until 1990. At that date, the rythm of pollution reduction increased. Today, organic pollution levels are probably lower than they were in the 1860s. However, it is striking to see that high levels of pollution were not a sufficient factor to trigger a strong political reaction. The high point reached at the beginning of the 1910s was not matched with an adequate control strategy, partly because the weight of structural and semiotic factors impeded its implementation.

\subsection{Management issues}

The Moselle pollution case is paradoxical because in France there was a variety of legal dipositions prohibiting the alteration of streams. The fishing law of 1829 and the decree of 1897 concerning the protection of fish forbid the use of poison to catch fish. The decree of 15 October 1810 on industrial factories (see page 1735) and its subsequent modifications (in 1917 and 1976) incorporated detailed provisions on the discharge of industrial wastewaters. Some ad hoc prefectoral orders were taken as early as the 1870 s to protect fish from industrial discharges in the most preserved areas of the basin ${ }^{14}$. It cannot be said, accordingly, that river managers were "unaware" of water pollution. The legal dispositions were simply inadequate to prevent an increase of pollution.

A first element of explanation is that the existing legislation did not elaborate on what was "industrial water pollution". The word itself never appeared in the actual texts. All endeavours to enact a new national framework specifically for water pollution issues failed repeatedly in 1911, 1920, 1923, 1932 and again in 1949 (Garcier, 2005, pp. 209-212). The existing laws used to control pollution were intrinsically contradictory. The fish laws considered the introduction of nefarious substances into the streams as a criminal behaviour, because it was a technique used by fish poachers. At the same time, the industrial legislation inaugurated by the decree of 1810 vindicated the discharge of industrial effluents if they respected some rather arbitrary norms. The result was a legal aporia, where the Administration endorsed industrial discharges while condemning their impact on fish.

There was in Lorraine no real feeling of urgency towards industrial pollution because between the 1870s and the 1910s, most stakeholders assumed that advances in science and technology would be able to solve the problems created by contemporary industry, especially for those industrial sec-

\footnotetext{
${ }^{14}$ Archives départementales des Vosges, files 329 S 1 and $20 \mathrm{M}$ 30 .
}

tors that incorporated a lot of science and research (e.g. steel making and mineral chemistry). Medical and technical publications mention various experiments to recover industrial waste, e.g. Freycinet (1868). There was a widespread alchemistic belief that some monetary value resided into industrial waste, much as faecal matter could be transformed into fertilizer or tar into aniline with a profit. Some new technical processes were needed to remove waste products. In the meantime, settling ponds or basins were advocated. The use of alkaline additives was recommended to tamper acids in excess. The lack of apparent interest in doing technical research on pollution was compounded by that widely shared belief that domestic wastewaters were more of a problem than industrial effluents. In his celebrated Traité d'hygiène industrielle, the Professor Léon Poincaré, a professor of public hygiene at the university of Nancy and a admirer of Pasteur's work on microbes, wrote:

"The discharge of waste in the rivers is much more dangerous than the discharge of industrial wastewaters." (Poincaré, 1886, p. 13)

In this context, the formulation of the concept of river "selfpurification" (in William Ripley Nichols' work on the Merrimack and Blackstone rivers in 1879) provided a strong support for the loose application of water pollution regulations. What need was there to treat industrial effluents if rivers could do it for free?

In any case, the application of prohibitory dispositions towards pollution would still have been extremely difficult. The Administration did not have the means to conduct systematic controls. Proving that a specific factory was to be blamed for inordinate water pollution was extremely difficult. In the 1920s, the creation of new coking facilities on the Orne and the Fensch had a dramatic impact on the aquatic fauna: some river sections became entirely devoid of life. On the Moselle itself, the creation of coking facilities in Pontà-Mousson and Thionville between 1923 and 1925 imperiled the fish stock ${ }^{15}$. The existence of an industrial cluster made the identification of culprits an impossible task. In this context, the industrialists could go on with legal and illegal discharges without much concern. Some of them simply avoided being caught red-handed:

"We still discharge in the Fensch the wastewaters of the pickling plants [...], which give a red color to the waters of the Fensch for some time after the emptying of the tanks. We will start operate in a few days a new tank for acid waters, which will allow us to discharge only during the night. This will not prevent the pollution of the river, but will make it less visible." 16

\footnotetext{
${ }^{15}$ Archives départementales de Moselle, file 5 S 10.

${ }^{16}$ Espace Archives Arcelor, file V10/77, Letter of the director of the Wendel factory of Fenderie to the Central Bureau in Hayange, 10 June 1924.
} 
Some fishermen associations indeed sued individual polluters for fish poisoning. However, the fishermen never contested the legitimacy of the industry. It was simply the alleged fraudulency of some discharges and their financial impact for the fishermen associations that were at stake. The few industrialists that were confronted on these issues did not hesitate to either buy the fishermen associations' silence or blackmail the Administration, as in this excerpt from a letter sent by the director of a major paper mill to an ingénieur des Eaux et Forêts:

"If the prefectoral order [prohibiting pollution] is ever used to file a lawsuit against us, we will close the Clairefontaine Paper Mills, and we will only reopen it when we are certain that we can go on with our production without being exposed to a bullying we cannot tolerate anymore. The Administration will have to take sides and state clearly if the activity of a factory that employs 1100 workers, pays seven millions of salaries and pays the State one million in taxes is less important than the grousing of [the president of the fishermen association of Raon]." ${ }^{, 17}$

The Administration yielded to this type of pressure for political reasons, in a context where the semiotic status of rivers made water alteration a legitimate option. In the 1980s, such attitudes towards pollution and the rivers were still prevalent - a clear sign of their long-lasting influence of river management. Here is an excerpt of a meeting at the préfecture of Meurthe-et-Moselle held in 1982 between the prefect and representatives of a soda maker:

"Mr. Montfort [CEO of Solvay France]: "Solvay feel they are attacked from all sides, except perhaps by the Administration. If we have to reduce pollution effectively, we will probably have to close one of the plants on the Meurthe and dismiss half of the workforce, to 1500 workers. Or maybe, the Administration could suspend the orders enjoining the soda factories to reduce pollution. [...]

The prefect remarks that the Administration has always adopted a soft stance on this issue, for example by differing the application of the orders requiring a decrease in discharges by $1^{\text {st }}$ January 1981." 18

After World War II, there was however an small evolution of the semiotic status of rivers, and most importantly, of pollution itself. At the end of the 1940s, some civil engineers had begun to worry about water provision in the region

\footnotetext{
${ }^{17}$ Archives départementales des Vosges, file 8 M 214. Letter of the director of the Clairefontaine Paper Mills to the Chief Ingénieur des Eaux et Forêts, 7 June 1929.

${ }^{18}$ Archives départementales de Moselle, file 1497 W 117. Minutes of the meeting with Solvay France, SA, 11 February 1982.
}

(Brunotte and Wargnier, 1949). Consumption was rapidly increasing due to economic and population growth and the refurbishment of distribution networks. In the foreseeable future, some shortages were to be feared. It fuelled a demand for water expertise and between 1949 and 1957 the State's technical bodies conducted studies on the regional water budget ${ }^{19}$. They showed that pollution was a factor of shortage because it impeded the use of some water resources. Pollution was rapidly growing and could not be seen as a criminal - i.e. deviant - behaviour anymore: pollution was a structural element of the water budget and a limiting factor to further industrial expansion. Controlling chronic pollution was a precondition of continued prosperity. A new pollution management strategy was devised which hinged on strategic planning of sectoral water uses and polluter-pay principle. The Water Law of 1964, which created the basin agencies, provided the legal framework required to enforce this new strategy. The basin agencies produce five-year strategic plans which lay out all the investments and policy initiatives programmed in the basin. The plans are financed by pollution and water abstraction taxes nominally paid by all water users in the basin except farmers. The level of the taxes is voted by a basin committee which includes representatives of the State, of water users and of basin stakeholders (environmentalists, for example). Even if the polluter-pay principle has been invoked from the start as the conceptual basis for taxation, the level of the taxes has never been high enough to become a true incentive. Until the 1990s, tax revenue was dimensioned to provide exactly the amount necessary to finance the wastewater plant equipment plan: pollution control was based on the mutualisation of the financing of pollution abatement equipment and not on cost internalisation incentives through taxation.

However, the Moselle was still strictly viewed as a source of water and the managers' aim was to insure mutual compatibility between all water uses within the basin. It allowed for the building of dams in the upper reaches of the basin: the goal was to limit the seasonal variations of hydraulicity so as to dilute pollution as much as possible. In direct accordance with the weight of historical structures, it was socially more acceptable to further modify the river than to act vigorously on pollution sources.

Two other points are worth noting. First, and despite all claims to the contrary from the river managers, it was not environmental concerns that gave birth to the basin agencies and the new tax-based policy instruments but the need to make sure that water shortages would not undermine the growth of the urban-industrial system in France. Second, the basin agency had to take into account the industrial consensus existing in the Moselle basin. In the beginning the

\footnotetext{
${ }^{19}$ Archives départementales de Meurthe-et-Moselle, file W 1245 111. See for example Société d'études pour l'alimentation en eau de l'Est de la France, "Alimentation en eau du bassin lorrain", Inventaire des besoins en eau, 1957.
} 
agency's legitimacy was very low and it met wide ranging opposition from a variety of basin stakeholders (industrialists and mayors in particular). In the basin committee, environmentalists and individual consumers were underrepresented. The basin committee and the basin agency management were very sensitive to the pressures exerted by the most powerful polluters in favour of the existing industrial consensus. In the 1970s, in the wake of the industrial crisis that undermined the economic base, the industrialists were able to negotiate only modest increases and spatial modulation of pollution taxes. As a consequence, until 1990, the overall decrease in organic pollution in the basin came from domestic pollution abatement (see Fig. 5).

The lasting presence of the industrial consensus began to crumble when a series of factors took momentum. The first one was the industrial crisis which challenged the industry's primacy as an economic sector. The crisis was dissociating the interests of the industrialists from the interests of the workers. If industry was not able to provide jobs any longer, why put up with its nefarious effects on the environment? Second, the pollution of the Moselle had become so severe in the 1960s that the downstream States had begun to take exception to the situation. In 1963, France, Germany and Luxembourg founded International Commissions for the Protection of the Moselle and the Sarre against pollution. Even if the commissions action was curtailed by their intergovernmental nature (until 1990, they were only a forum of discussion between governments), they were a symptom of the political magnitude reached by the pollution problem of the Moselle and a channel through which downstream States (and co-members of the European Economic Community) exerted pressure on France. In the 1960s, the main issue was organic pollution. However, in the 1970s, the priorities changed and the question of salt discharges in the Meurthe came to the forefront. That was linked to the heated debate surrounding the salt content of the Rhine. In the 1970s, the Moselle system contributed 27\% to the French share of chloride discharge in the Rhine (the remaining $73 \%$ came from the potash mines in Alsace). The local administration was extremely reluctant to take action against pollution and the industrial consensus prevented pressures from the French diplomacy to trickle down to either the prefect or the basin agency. Overall, the situation was stalled and the sectoral management principles inherited from the "planning" strategy proved inadequate to deal with emerging pollution problems (e.g. diffuse pollution).

The main factor leading to a strategic turnaround in water pollution management was the Sandoz accident in Basel (Switzerland) on 1 November 1986. The water the firemen used to put the fire out flowed to the Rhine, loaded with chemicals. Fish in the river was eradicated, drawing large media coverage and public attention. Marco Verweij has related the circumstances surrounding the endorsement of the Rhine Action Program by all riparian States in 1987 (Verweij, 1999, 2000). For the Moselle basin, the accident led to the adoption of a new "international and environmental" strategy that had two main consequences. The Rhine Action Program was translated into regional objectives laid out by the basin agency (1990). Pollution taxes rates were increased by roughly $60 \%$ over a period of eight years. The pollution discharges, already severely curtailed by the industrial crisis, were further reduced (see Fig. 5). In the new strategy (and in the new action program for the basin), the environment was given some consideration. It was a consequence of the influence of the German and the Dutch examples and the logical outcome of a national debate on the functions of natural ecosystems (1990). Its conclusions were that some tasks were better carried out and at a lesser cost by functional ecosystems (e.g. wetlands) than by artificial means. Environmental protection was not a matter of principles: it was based on sound accounting.

\section{Conclusions}

In the second book of The Orator, Cicero extols the virtues of history, "magistra vitae" (teacher of life). He probably did not think of river management at the time but with a distance, his expression is a good summary - mutatis mutandis - of our argument. There is more to history than a mere remembrance of things past. An understanding of the forces that have shaped the materiality and the images of river systems is necessary to grasp river management in the past but also in the present because historical structures have strong inertia. This aspect is curiously absent from the literature on the environmental history of the twentieth century. In "Something New under the Sun", J. R. McNeill argues very convincingly that the twentieth century saw environmental changes unmatched in human history (McNeill, 2000). However, the cultural "conditions of possibility" of such changes remain somewhat elusive. McNeill shows that the "big ideas" (ideologies that developed in the twentieth century) have had a strong environmental impact, even if they were not specifically environmental per se. I think that an important factor enabling environmental change in the twentieth century has been the standing conferred to natural objects. It does not only derive from very wide ethical and philosophical backgrounds (as in Lynn White's famous article on "The Historical Roots of Our Ecological Crisis") or from McNeill's "big ideas" but also to very pragmatic cultural values invested in forests, rivers, etc.

For the Moselle, the lesson to be learnt is that some mental structures and power relations (what we termed "industrial consensus") have prevented the conception and implementation of successful pollution management strategies. This analytical framework could explain environmental degradation in other settings and more specifically, in areas where large concentrations of industrial activities can be found. It has been shown that industrial consensus explained the high level of air pollution in the Ruhr region (Uekoetter, 2002). In 
another example, the Yangtse river in China has undergone massive changes in the last decade. It has been dammed to prevent floods and enable irrigation, with severe consequences on sediment transit. In the process, many localities and historical sites of importance have been permanently flooded, thus reneging on the cultural standing of the river in Chinese culture. Human pressures on the river have been compounded by heavy pollution and fishing (Diamond, 2004). As a consequence, in August 2007, new reports declared that the Yangtze dolphin, locally known as "baiji", had gone extinct. It used to be a symbol of the river and an auspicious sign for fishermen. Such visible modifications of the river environment express deep changes in the relationship the Chinese society entertains with the river and the risks and values connected to it.

There is a second lesson to be learnt for public environmental management. The creation of formally democratic and open forums in Lorraine (such as the basin committee) did not bring by itself an improvement of water quality in the basin. It means that policy initiatives cannot ignore structural conditions that shape river basins' functioning, image and management. The case of the Moselle shows that stakeholders' participation will not necessarily produce an environmentally optimal outcome and that consensus over management principles is no indication of the desirability of the principles themselves from an environmental point of view. Caution is required in front of the calls for "integrated management" and "stakeholder participation" in a drainage basin when they ignore the reality of power relations and the weight of historical structures.

Acknowledgements. I would like to thank the two anonymous referees for their sharp and stimulating comments. Figure 4 was made with PhilCarto, a free statistical cartography software: http://perso.club-internet.fr/philgeo.

Edited by: S. Barles

\section{References}

Barca, S.: Enclosing the River: Industrialisation and the 'Property Rights' Discourse in the Liri Valley (South of Italy), 1806-1916, Environ. Hist., 13, 3-23, 2007.

Barles, S.: L'Invention des eaux usées: l'assainissement de Paris, de la fin de l'Ancien Régime la seconde guerre mondiale, in: Le démon moderne: la pollution dans les sociétés urbaines et industrielles d'Europe, $\mathrm{XIX}^{\mathrm{e}}-\mathrm{XX}^{\mathrm{e}}$ siècles, edited by Bernhardt, $\mathrm{C}$. and Massard-Guilbaud, G., pp. 129-156, Presses universitaires Blaise Pascal, Clermont-Ferrand, 2002.

Barles, S.: Feeding the city: Food consumption and flow of nitrogen, Paris, 1801-1914, Sci. Total Environ., 375, 48-58, 2007.

Beck, U.: Rosk Society: Towards a New Modernity, Sage, London, (First German edition: 1986), 1992.

Blackbourn, D.: The Conquest of Nature: Water, Landscape, and the Making of Modern Germany, W.W. Norton, New York City, 2006.
Bloch, M.: Avènement et conquêtes du moulin à eau, Annales d'histoire économique et sociale, 10, 538-563, 1935.

Boudon, R.: À quoi sert la notion de structure? Essai sur la signification de la notion de structure dans les sciences humaines, Gallimard, Paris, 1968.

Bour, R. (Ed.): L'Épopée industrielle, Encyclopédie illustrée de la Lorraine: Histoire des sciences et techniques, Éditions Serpenoise - Presses Universitaires de Nancy, Metz-Nancy, 1995.

Bravard, J.-P.: La métamorphose des rivières des Alpes françaises de la fin du Moyen-Âge à l'époque moderne, Bulletin de la Société Géographique de Liège, 25, 145-157, 1989.

Bravard, J.-P. and Magny, M., eds.: Les Fleuves ont une histoire: Paléo-environnement des rivières et des lacs français depuis 15000 ans, Archéologie d'Aujourd'hui, Errance, Paris, 2002.

Brunotte, R. and Wargnier, R.: Étude sur l'alimentation en eau potable des communes de Meurthe-et-Moselle, Annales de la Direction Générale du Génie rural et de 1'Hydraulique Agricole, 70, 229-462, 1949.

Buschenfeld, J.: Fluesse und Kloaken: Umweltfragen im Zeitalter der Industrialisierung (1870-1918), Klett-Cotta, Stuttgart, 1997.

Cermakian, J.: The Moselle: river and canal from the Roman Empire to the European Economic Community, no. 14 in Research Papers, Department of Geography, University of Toronto, University of Toronto Press, Toronto, 1975.

Chaney, S. L.: Visions and Revisions of Nature. From the Protection of Nature to the Invention of the Environment in the Federal Republic of Germany, 1945-1975, Phd in History, University of North Carolina, Chapel Hill, 1996.

Cioc, M.: The Rhine: an Eco-biography, 1815-2000, University of Washington Press, Seattle, 2002.

Corvol, A. (Ed.): Les Sources de l'histoire de l'environnement: le XIX ${ }^{\mathrm{e}}$ siècle, L'Harmattan, Paris, 1999.

Corvol, A. (Ed.): Les Sources de l'histoire de l'environnement: le $\mathrm{XX}^{\mathrm{e}}$ siècle, L'Harmattan/Direction des Archives de France, Paris, 2003.

Cronon, W.: Nature's Metropolis: Chicago and the Great West, W.W. Norton, New York, 1992.

de Launay, L.: Les réserves mondiales de minerai de fer, Annales de Géographie, 21, 97-108, 1912.

Descola, P.: Leçon inaugurale faite le 29 mars 2001, Collège de France, Paris, 2001.

Descola, P.: Par-delà nature et culture, Gallimard, Paris, 2005.

Diamond, J.: Collapse: How Societies Choose to Fail or Succeed, Viking, New York, 2004.

Duby, G.: The Legend of Bouvines: War, Religion, and Culture in the Middle Ages, University of California Press, Berkeley, 1990.

Dülmen, R. V. and Labouvie, E.: Die Saar: Geschichte eines Flusses, Rohrig Verlag, St. Ingbert, 1992.

Freycinet, L.-C.: Rapport supplémentaire sur l'assainissement industriel et municipal en France et à l'étranger, Dunod, Paris, 1868.

Garcier, R. J.: La pollution industrielle de la Moselle française: naissance, développement et gestion d'un problème environnemental, 1850-2000, Phd in geography, Université Lumière Lyon 2, 2005.

Gazzaniga, J.-L., Ourliac, J.-P., and Larrouy-Castera, X.: L'Eau: usages et gestion, Litec, Paris, 1998.

Girel, J.: La prise en compte de l'histoire dans la gestion des corridors fluviaux: les enseignements des aménagements anciens, 
Revue de Géographie de Lyon, 71/4, 341-352, 1996.

Gumprecht, B.: The Los Angeles River: Its Life, Death and Possible Rebirth, Johns Hopkins University Press, Baltimore, 2001.

Haby, R. (Ed.): Les Houillères lorraines et leur région, Éditions SABRI, Paris, 1965.

Held, T.: Erste Hilfe für Todkranken: der technische Ausbau des Emschersystems, in: Vor Ort im Ruhrgebiet: eine geographischer Führer, edited by Duckwitz, G. and Hommel, M., 42-43, Pomp, Essen, 2002.

Houpert, A.: La Moselle canalisée: des Nautae gallo-romains au CAMIfemo, Chambre de commerce et d'industrie de Metz, Metz, 1932.

Kraemer, H.-H.: Von Dorfbrunnen zum Wasserwerk - Geschichte der Trinkwasserversorgung an der Saar, Saarland Bibliothek, Gollenstein Verlag, Blieskastel, 1999.

Laakkonen, S. and Lehtonen, P.: A quantitative analysis of discharges into the Helsinki urban sea area in 1850-1995, European Water Management, 2, 30-39, 1999.

Laffitte, L.: L'évolution économique de la Lorraine, Annales de Géographie, 21, 393-417, 1912.

Latour, B.: We Have Never Been Modern, Harvard University Press, Cambridge, (First French edition: 1991), 1993.

Latour, B.: Politics of Nature: How to Bring the Sciences into Democracy, Harvard University Press, Cambridge, (First French edition: 1999), 2004.

Le Masson and Le Joindre: Mémoire sur la navigation de la Moselle, Mémoires de l'Académie Royale de Metz, pp. 251-370, downloadable at http://gallica.bnf.fr/SocietesSavantes/Lorraine. htm, 1835.

Le Roy-Ladurie, E.: Times of Feast, Times of Famine: A History of Climate Since the Year 1000, Farrar, Straus and Giroux, New York, (First French edition: 1967), 1988.

McNeill, J. R.: Something New Under the Sun: An Environmental History of the Twentieth-Century World, W.W. Norton, New York, 2000.

Meybeck, M.: Riverine quality at the Anthropocene: Propositions for global space and time analysis, illustrated by the Seine River, Aquatic Sciences, 64, 376-393, 2002.

Meybeck, M., Chapman, D., and Helmer, R., eds.: Global Freshwater Report: a First Assessment, Blackwell, Oxford, 1989.

Meybeck, M., de Marsilly, G., and Fustec, E. (Eds.): La Seine en son bassin: Fonctionnement écologique d'un système fluvial anthropisé, Elsevier, Paris, 1998.
Meybeck, M., Lestel, L., Bonté, P., Moillerond, R., Coline, J.-L., Rousselot, O., Hervé, D., de Pontevès, C., Grosbois, C., and Thévenot, D. R.: Historical perspective of heavy metals contamination $(\mathrm{Cd}, \mathrm{Cr}, \mathrm{Cu}, \mathrm{Hg}, \mathrm{Pb}, \mathrm{Zn}$ ) in the Seine River basin (France) following a DPSIR approach (1950-2005), Science of the Total Environment, 375, 204-231, 2007.

Petts, G., Roux, A.-L., and Moeller, H. (Eds.): Historical Change of Large Alluvial Rivers: Western Europe, Wiley, Chichester, 1989.

Poincaré, L.: Traité d'hygiène industrielle, Masson, Paris, 1886.

Roux, A.-L. (Ed.): Cartographie polythématique appliquée à la gestion écologique des eaux. Étude d'un hydrosystème fluvial: le Haut-Rhône français, Éditions du CNRS, Lyon, 1982.

Santos, M. A. and Filho, W. L.: An analysis of the relationship between sustainable development and the anthroposystem concept, International Journal of Environment and Sustainable Development, 4, 78-87, 2005.

Scarpino, P. V.: Large floodplain rivers as human artifacts: A historical perspective on ecological integrity, Tech. Rep. LTRMP 97-S003, U.S. Geological Survey - Environmental Management Technical Center, Onalaska (Wisconsin), 1997.

Steinberg, T.: Nature Incorporated: Industrialization and the Waters of New England, Cambridge University Press, Cambridge, 1st edition 1992, 2001.

HBL: Du Charbon et des hommes: histoire des houillères du bassin de Lorraine, Éditions Serpenoise, Metz, 1993.

Uekoetter, F.: A look into the Black Box: why air pollution was undisputed in interwar Germany, in: Le démon moderne: la pollution dans les sociétés urbaines et industrielles d'Europe, $\mathrm{XIX}^{\mathrm{e}}$ $-\mathrm{XX}^{\mathrm{e}}$ siècles, edited by: Bernhardt, C. and Massard-Guilbaud, G., 239-255, Presses universitaires Blaise Pascal, ClermontFerrand, 2002.

Verweij, M.: A Watershed on the Rhine: changing approaches to international environmental cooperation, Geojournal, 47, 453461, 1999.

Verweij, M.: Transboundary Environmental Problems and Cultural Theory: the Protection of the Rhine and the Great Lakes, Palgrave, New York, 2000.

Weigelt, C.: Die Schädigung von Fischzucht durch Industrie und Haus-abwässer, Archiv für Hygiene, 3, 39-117, 1885.

Weigelt, C.: L'Assainissement et le repeuplement des rivières, Hayez, Brussels, 1903.

White, R.: The Organic Machine: The Remaking of the Columbia River, Hill and Wang, New York, 1995.

Williams, M.: Americans and their Forests: a Historical Geography, Cambridge University Press, Cambridge, 1992. 